\title{
Critical Issues in Translational and Clinical Research for the Study of New Technologies to Enhance Bone Repair
}

\author{
By Jörg Goldhahn, MD, Bruce Mitlak, MD, Per Aspenberg, MD, PhD, John A. Kanis, MD, René Rizzoli, MD, and \\ Jean-Yves Reginster, MD, PhD, on Behalf of the GREES (Group for the Respect of Ethics and Excellence in Science) \\ Working Group on Bone Fracture-Healing
}

\begin{abstract}
Osteoporosis increases fracture risk, especially in metaphyseal bone. Fractures seriously impair function and quality of life and incur large direct and indirect costs. Although the prevention of fractures is certainly the option, a fast and uneventful healing process is optimal when fractures do occur. Many new therapeutic strategies have been developed to accelerate fracture-healing or to diminish the complication rate during the course of fracture-healing. However, widely accepted guidelines are needed to demonstrate the positive or negative interactions of bioactive substances, drugs, and other agents that are being used to promote fracture-healing. For each study design, the primary study goal should be indicated. Outcome variables should include both objective and subjective parameters. The guidelines should be harmonized between European and American regulatory authorities to ensure comparability of results of studies and to foster global harmonization of regulatory requirements.
\end{abstract}

\section{Quality of Life After Fractures}

$\mathrm{F}$ ractures greatly impair the quality of life of the affected individual. Although adequate surgical treatment might restore full function and quality of life, there remains a finite risk of permanent deficit as well as the risk of a complication during the course of healing ${ }^{1,2}$. The risk of permanent deficits or complications depends on fracture characteristics, patient-related risk factors, and treatment-specific complications ${ }^{3-7}$. Complications have direct consequences for the patient and also have serious socioeconomic impact. A prolonged rehabilitation process and a delayed return to work, the need for salvage procedures, or a permanent need for care will all require additional resources.

Osteoporosis greatly aggravates the problems mentioned above. It increases the risk of fracture ${ }^{8}$, especially in metaphyseal regions; it impairs function and quality of life'; and it causes marked direct and indirect costs ${ }^{10-12}$. An impaired ability to walk after a hip fracture or a decrease in grip strength after a radial fracture are examples of a possible loss of independence, the need for additional care, and increased costs ${ }^{13-15}$.

Although the prevention of fractures is certainly the goal, a fast and uneventful healing process is optimal when fractures do occur. Many new therapeutic strategies have been developed to accelerate fracture-healing or to diminish the complication rate during the course of fracture-healing ${ }^{16,17}$. Existing treatment protocols have provided evidence that some approaches can influence fracture-healing ${ }^{18}$. However, widely accepted guidelines are needed to demonstrate the positive or negative interactions of the bioactive substances, drugs, and other agents that are being used to promote fracture-healing in clinical trials.

\section{Potential Targets for Drugs}

Fracture-Healing

$\mathrm{C}$ racture repair involves different stages of tissue differentiF ation, certain aspects of which resemble embryological skeletal development. The initial injury provokes an inflammatory response, followed by a periosteal response and endochondral bone formation. Cartilage resorption and woven bone formation are the next steps. The final stage of fracture repair is secondary bone formation through coupled remodeling $^{19}$. The duration of the different phases greatly varies, depending on location, characteristics of the fracture, patientrelated risk factors, and treatment. Diaphyseal fracture-healing and metaphyseal fracture-healing demonstrate substantial biomechanical, histological, and radiographic differences that can challenge the investigator.

Disclosure: The authors did not receive any outside funding or grants in support of their research for or preparation of this work. One or more of the authors, or a member of his or her immediate family, received, in any one year, payments or other benefits of less than $\$ 10,000$ or a commitment or agreement to provide such benefits from a commercial entity (Eli Lilly and Company). No commercial entity paid or directed, or agreed to pay or direct, any benefits to any research fund, foundation, division, center, clinical practice, or other charitable or nonprofit organization with which the authors, or a member of their immediate families, are affiliated or associated. 
The Journal of Bone \& Joint Surgery - JBjS. org Volume $90-\mathrm{A} \cdot$ SUPPLEMENT $1 \cdot 2008$
Critical Issues in Translational and Clinical Research for the Study of New Technologies to Enhance Bone Repair
Several drugs and other active substances have been shown to interact with these processes during fracturehealing ${ }^{18,20}$. Growth factors other than bone morphogenetic proteins (BMPs) are expressed during fracture repair, and these growth factors have been applied with or without a carrier with successful results in animal models but not in humans ${ }^{21-25}$.

Bone morphogenetic proteins are part of a complex signaling system consisting of several BMP molecules, different receptors, and soluble antagonists. BMPs also induce osteoclastic bone resorption, and this response often comes before the bone formative response $e^{26,27}$. It has therefore been suggested that, in some situations, BMP treatment could be complemented with a bisphosphonate to provide protection from bone resorption ${ }^{28}$, but the possible anabolic, synergistic effect of these two drugs will have to be verified in vivo. BMP signaling and the response to BMPs are both dependent on mechanical loading ${ }^{29,30}$. BMPs stimulate fracture repair effectively in most animal models, but the need to apply massive doses of the protein is a problem. Two types of BMPs are currently approved for the treatment of fractures. In addition, parathyroid hormone has also been shown to stimulate fracture repair in rats ${ }^{31,32}$; however, the most dramatic effects come late in the process, after bridging bone has been developed ${ }^{33}$.

There are at least four different receptors for prostaglandin $E_{2}$, with separate distribution and separate second messenger systems. Selective agonists for the receptors EP2 and EP4 have been shown to stimulate fracture repair in rodent and dog models $s^{34,35}$.

Statins can activate the promoter of the BMP-2 gene and improve bone formation in rats ${ }^{36}$ and fracture repair in mice ${ }^{37}$. So far, no data are available that prove this effect in other species or in humans.

Bone mass is also regulated from the hypothalamus by way of the adrenergic system. In consequence, propranolol, a common beta-blocker, increases bone mass in wild-type mice ${ }^{38}$ and enhances the repair of bone defects in rats ${ }^{39}$.

Rather than relying solely on the stimulation of bone formation, it is also possible to inhibit resorption with the use of bisphosphonates, leading to a net anabolic effect that enhances repair ${ }^{40}$.

\section{Fracture Fixation}

Several biomechanical tests have shown that pull-out or shear strength and other characteristic variables of fixation correlate with the amount or structure of bone that surrounds the fixation device. Pull-out and shear tests of single screws have revealed that there is a linear correlation between both of these loading modes and bone mineral density as well as cortical thickness along screws ${ }^{41}$. Limited cyclic testing of experimental spinal implants showed that subsidence under perpendicular loading correlates best (inversely) with the mean space between trabeculae, which corresponds with trabecular separation ${ }^{42}$. Dayer et al., using micro-computed tomography measurement, found that pull-out of titanium rods correlates with bone-to-implant contact ${ }^{43}$. Thus, drugs or treatment regimens that have an effect on bone remodeling are also likely to in- fluence the quality of fixation. This theory has been proven in animal experiments ${ }^{43-46}$ as well as in humans ${ }^{47-49}$. Just as bone formation can be enhanced with the use of anabolic drugs ${ }^{50,51}$, fixation can be improved with the use of bisphosphonates to inhibit resorption ${ }^{52}$. Bisphosphonates can be applied easily to hydroxyapatit $e^{53}$ or linked to metal surfaces, and these methods have been shown to improve mechanical fixation of metal screws in bone in animal models ${ }^{47,54}$.

\section{Current Regulatory Status}

There is currently no European regulatory guidance for clinical evaluation of pharmacologic therapies intended to augment the fracture-healing process. However, two products have been approved by the European Medicines Agency (EMEA), which provides information and experience to aid future guidance development. The primary outcomes for these product studies were different and included a radiographic end point, the complication rate, or a composite of radiographic, functional, and complication rates.

One approved product is InductOs recombinant human (rh)BMP-2 (Wyeth Pharmaceuticals, Madison, New Jersey), which is indicated for use in the specific situation of "single level between L4 and S1 anterior lumbar spine fusion as a substitute for autogenous bone graft in adults with degenerative disc disease who have had at least six months of nonoperative treatment for this condition." ${ }^{\text {55 }}$ It is also indicated "for the treatment of acute tibial fractures in adults as an adjunct to standard care using open fracture reduction and intramedullary (IM) nail fixation." ${ }^{35}$ The two indications were granted on the basis of successful conduct in studies of the specific fractures.

For the indication for use during spinal fusion, the primary efficacy variable was spinal fusion measured by independent radiographic reviewers. Pain and disability status was also measured by the subjects with use of the Oswestry Low Back Pain Disability Index Questionnaire ${ }^{56}$. The study included 279 men and women who were older than eighteen years of age and who had degenerative disc disease and one or more of the following: (1) instability, (2) osteophyte formation, (3) decreased disc height, (4) thickening of the ligamentous tissue, (5) disc degeneration or herniation, and/or (6) facet joint degeneration. Subjects were required to have a baseline Oswestry score of 35 or greater, no greater than grade-1 spondylolisthesis, single-level symptomatic degenerative involvement from L4 to S1, and no response to six months of nonoperative treatment ${ }^{57}$.

For the indication for use in the treatment of acute tibial fracture, the primary efficacy variable was the proportion of patients requiring a secondary intervention to promote fracturehealing within twelve months of definitive wound closure. The study included 450 patients with open tibial shaft fractures that required surgical management including use of an intramedullary nail. Patients at all levels of fracture severity were included; only those at high risk of amputation (Gustilo-Anderson type IIIC $^{58,59}$ ) were excluded ${ }^{60}$.

The other product that has received marketing approval in Europe is Osigraft recombinant human osteogenic protein-1 
The Journal of Bone \& Joint Surgery - JBjS. org Volume $90-\mathrm{A} \cdot$ SUPPLEMENT $1 \cdot 2008$
Critical Issues in Translational and Clinical Research for the Study of New Technologies to Enhance Bone Repair
(rhOP-1) or BMP-7 (Stryker Biotech, Hopkinton, Massachusetts), which is indicated for "the treatment of nonunion of the tibia of at least 9 month duration, secondary to trauma in skeletally mature patients, in cases where previous treatment with autograft has failed or use of autograft is unfeasible." ${ }^{\text {61 }}$

In the study of this product, 122 patients with nonunion of the tibia treated with Osigraft or autograft were included ${ }^{62}$. For demonstration of efficacy, the protocol required all of the following criteria to be demonstrated by nine months: (1) evidence of cortical and/or trabecular bridging of the nonunion gap in three of four radiographic views or bridging of three or more cortices, (2) full weight-bearing in the affected limb, (3) patient not suffering from severe pain in the affected limb, (4) no surgical intervention at the nonunion site with the intention of promoting healing, and (5) absence of chronic donor-site pain. Patient outcomes were assessed with use of a visual analog scale and the Short Form-36 physical functioning indices.

Each of these treatments includes both a growth factor and an implantable device intended to permit local delivery. In the European Union, the products were reviewed and approved by the EMEA Committee for Medicinal Products for Human Use (CHMP) as medicinal products because the principal action of the products is pharmacologic ${ }^{63}$. In contrast, the review and approval of InductOs was the responsibility of the Center for Devices and Radiological Health at the United States Food and Drug Administration (FDA).

\section{Requirements for New Regulatory Guidance}

$\mathrm{I}^{\mathrm{n}}$ nvestigators, sponsors, and participating centers of clinical studies should make certain that any trials testing new substances with proposed effects on fracture-healing will be accepted by the regulatory authorities (both the FDA and the EMEA). Additionally, the outcome of the study should be of substantial interest and medical relevance to the scientific community and, last but not least, relevant for the patient. It will be of substantial value to develop harmonized guidelines for any new locally applied as well as systemic treatments that become available for testing in patients with fractures.

On the basis of the characteristics of fracture-healing and fixation, two separate study goals are appropriate-the reduction of fracture-healing complications, and the acceleration of fracture-healing. The intended goal should then determine subsequent study methodology. Whereas the approach to studying spinal fusion requires the staging of fracture-healing at defined points as well as precise definitions of expected complications, the approach to studying tibial fracture requires repeated measures of fracture-healing. The second approach is more complex because definitive methods for monitoring fracture-healing have not yet been established.

Radiographic evaluation of fracture-healing incorporates several parameters, including the assessment of the disappearance of fracture lines and the presence of cortical bridging as well as a determination of the diameter and shape of the callus. Radiographic scoring of fracture-healing has largely relied on investigator assessment, and currently there are no in vivo techniques to quantify healing in mechanical terms for fractures involving mainly trabecular bone. Further validation of radiographic scoring should be undertaken, and semiautomated methods are required ${ }^{64}$. Radiographic evaluation may occur at multiple time-points during the healing process, with the aim of measuring the time taken to reach a defined status (e.g., cortical bridging), or may occur at a single predetermined time-point at which patients reach a common clinical milestone (e.g., pain-free loading). Newer imaging techniques, such as computed tomography, may enhance the ability to assess fracture-healing ${ }^{65}$. Radiostereometric analysis was introduced as a way of measuring the increase in stiffness during fracture-healing and has the potential to monitor fracture-healing in vivo ${ }^{66}$; however, use of this method in large clinical trials is not yet feasible.

In addition to objective outcome parameters, the equally important parameter of patient self-assessment should be incorporated in clinical studies on fracture-healing. Patient responses to questions regarding function and quality of life help to quantify relevant therapeutic effects for individuals as well as for groups of patients ${ }^{67}$. The parameter of self-assessment should also correspond to the holistic International Classification of Functioning, Disability and Health (ICF) approach of the World Health Organization through the inclusion of questions that evaluate how the disability (e.g., a distal radial fracture) affects different levels of interpersonal interaction ${ }^{68}$. If we can assume that return of function (to a certain extent) parallels fracture-healing, then we can utilize self-assessment as a repeated measure of fracture-healing rather than subjecting a patient to the adverse effects of radiography. Important functional end points also include weight-bearing, pain on palpation or on weight-bearing, and time to return to work. Clear rules regarding validity and reliability exist that should help in the choice of an appropriate patient self-assessment instrument ${ }^{67}$. Only functional instruments that are validated for the particular fracture site should be used.

In July 2005, the CHMP provided guidance on patientreported outcomes ${ }^{69}$. The guidance document indicated that efficacy end points and health-related quality of life can be coprimary end points. Alternatively, the hierarchical testing of end points may be applied.

Therefore, in the clinical evaluation of treatments for fracture-healing, functional outcomes and complication rates should be supplemented by radiographic scoring of the fracture-repair process. If one of the outcome variables is complication rates during fracture-healing, the expected complications have to be exactly defined prior to the study. An independent review panel is required for the evaluation and classification of each recorded complication.

Other information in the CHMP guidance document may be relevant to the assessment of fracture-healing. The document states that both generic and disease-specific tools can be used. A global claim of health-related quality of life requires demonstration of robust improvements in all or the most important and clinically relevant domains of functioning that impact the patient's quality of life. Specific claims may be 
The Journal of Bone \& Joint Surgery $\cdot$ JBjS. Org VOLUMe $90-\mathrm{A} \cdot$ SUPPLEMENT $1 \cdot 2008$
Critical Issues in Translational and Clinical Research for the Study of New Technologies to Enhance Bone Repair sought on a subset of domains of the ICF if prespecified in the analysis plan. A conceptual framework is needed to justify instrument and domain selection, appropriateness, and psychometric properties. The amount of change that is required to be considered as clinically meaningful needs to be prespecified. All domains must be reported irrespective of negative or positive change or no change at all. Generally, validation should be completed before the health-related quality-of-life instrument is used in therapeutic confirmatory trials. Finally, the same study should not be used to validate the instrument and to test the health-related quality-of-life change.

\section{Conclusions}

$\mathrm{T}$ here is a clear need for guidelines for clinical studies of therapeutic medicinal products that are targeted at or are suggested to influence fracture-healing. For each study design, it should be stated whether reduction of a prospectively defined complication rate or acceleration of fracture-healing is the primary study goal. Outcome variables should include objective as well as subjective parameters. The guidelines should be harmonized between European and American regulatory authorities to ensure comparability of results of studies.

NotE: The GREES (Group for the Respect of Ethics and Excellence in Science) working group on bone fracture-healing consists of the following individuals: Eric Abadie, Per Aspenberg, Peter Augat, Maria-Luisa Brandi, Nansa Burlet, Arkadi Chines, Pierre Delmas, Will Dere, Isabelle DupinRoger, Dominique Ethgen, Jörg Goldhahn, John A. Kanis, Joel Krasnow, Gottfried Kreutz, Andrea Laslop, Frits Lekkerkerker, David Marsh, Bruce Mitlak, Sif Ormarsdottir, Jean-Yves Reginster, René Rizzoli, Art Santora, Gerhard Schmidmaier, and Michael Wagener.

Corresponding author:

Jörg Goldhahn, MD

Department of Research, Schulthess Klinik, Lengghalde 2, Zurich 8008, Switzerland. E-mail address: joerg.goldhahn@kws.ch

\section{References}

1. Butcher JL, MacKenzie EJ, Cushing B, Jurkovich G, Morris J, Burgess A, McAndrew M, Swiontkowski M. Long-term outcomes after lower extremity trauma. J Trauma. 1996;41:4-9.

2. Mackenzie EJ, Bosse MJ, Pollak AN, Webb LX, Swiontkowski MF, Kellam JF, Smith DG, Sanders RW, Jones AL, Starr AJ, McAndrew MP, Patterson BM, Burgess AR, Castillo RC. Long-term persistence of disability following severe lower-limb trauma. Results of a seven-year follow-up. J Bone Joint Surg Am. 2005; 87:1801-9.

3. Yi L, Jingping B, Gele J, Baoleri X, Taixiang W. Operative versus non-operative treatment for thoracolumbar burst fractures without neurological deficit. Cochrane Database Syst Rev. 2006;4:CD005079.

4. Parker MJ, Gurusamy K. Internal fixation versus arthroplasty for intracapsular proximal femoral fractures in adults. Cochrane Database Syst Rev. 2006;4:CD001708.

5. Bhandari M, Devereaux PJ, McKee MD, Schemitsch EH. Compression plating versus intramedullary nailing of humeral shaft fractures - a meta-analysis. Acta Orthop. 2006; $77: 279-84$.

6. Handoll HH, Gibson JN, Madhok R. Interventions for treating proximal humeral fractures in adults. Cochrane Database Syst Rev. 2003;4:CD000434.

7. Handoll HH, Madhok R. Surgical interventions for treating distal radial fractures in adults. Cochrane Database Syst Rev. 2003;3:CD003209.

8. Reginster JY, Burlet N. Osteoporosis: a still increasing prevalence. Bone. 2006;38(2 Suppl 1):S4-9.

9. Johnell $\mathrm{O}$, Kanis JA. An estimate of the worldwide prevalence and disability associated with osteoporotic fractures. Osteoporos Int. 2006;17:1726-33.

10. Chrischilles E, Shireman T, Wallace R. Costs and health effects of osteoporotic fractures. Bone. 1994;15:377-86.

11. Rabenda V, Manette C, Lemmens R, Mariani AM, Struvay N, Reginster JY. The direct and indirect costs of the chronic management of osteoporosis: a prospective follow-up of 3440 active subjects. Osteoporos Int. 2006;17:1346-52.

12. Burge $R$, Dawson-Hughes $B$, Solomon $D H$, Wong JB, King $A$, Tosteson A. Incidence and economic burden of osteoporosis-related fractures in the United States, 2005-2025. J Bone Miner Res. 2007;22:465-75.

13. Lübbeke A, Stern R, Grab B, Herrmann F, Michel JP, Hoffmeyer P. Upper extremity fractures in the elderly: consequences on utilization of rehabilitation care. Aging Clin Exp Res. 2005;17:276-80.

14. Gabriel SE, Tosteson AN, Leibson CL, Crowson CS, Pond GR, Hammond CS, Melton $\sqcup$ 3rd. Direct medical costs attributable to osteoporotic fractures. Osteoporos Int. 2002;13:323-30.

15. Lippuner K, Golder M, Greiner R. Epidemiology and direct medical costs of osteoporotic fractures in men and women in Switzerland. Osteoporos Int. 2005;16 Suppl 2:S8-S17.
16. Schmidmaier G, Lucke M, Schwabe P, Raschke M, Haas NP, Wildemann B. Collective review: bioactive implants coated with poly(D,L-lactide) and growth factors IGF-I, TGF-beta1, or BMP-2 for stimulation of fracture healing. J Long Term Eff Med Implants. 2006;16:61-9.

17. Kain MS, Einhorn TA. Recombinant human bone morphogenetic proteins in the treatment of fractures. Foot Ankle Clin. 2005;10:639-50, viii.

18. Aspenberg P. Drugs and fracture repair. Acta Orthop. 2005;76:741-8.

19. Gerstenfeld LC, Cullinane DM, Barnes GL, Graves DT, Einhorn TA. Fracture healing as a post-natal developmental process: molecular, spatial, and temporal aspects of its regulation. J Cell Biochem. 2003;88:873-84.

20. Skripitz R, Aspenberg P. Parathyroid hormone-a drug for orthopedic surgery? Acta Orthop Scand. 2004;75:654-62.

21. Kawaguchi H, Kurokawa $T$, Hanada $K$, Hiyama $Y$, Tamura M, Ogata $E$, Matsumoto T. Stimulation of fracture repair by recombinant human basic fibroblast growth factor in normal and streptozotocin-diabetic rats. Endocrinology. 1994:135:774-81.

22. Chen WJ, Jingushi S, Aoyama I, Anzai J, Hirata G, Tamura M, Iwamoto $Y$. Effects of FGF-2 on metaphyseal fracture repair in rabbit tibiae. J Bone Miner Metab. 2004;22:303-9.

23. Schmidmaier G, Wildemann B, Ostapowicz D, Kandziora F, Stange R, Haas NP, Raschke M. Long-term effects of local growth factor (IGF-I and TGF-beta 1) treatment on fracture healing. A safety study for using growth factors. J Orthop Res. 2004;22:514-9.

24. Raschke M, Kolbeck S, Bail H, Schmidmaier G, Flyvbjerg A, Lindner T, Dahne M, Roenne IA, Haas N. Homologous growth hormone accelerates healing of segmental bone defects. Bone. 2001;29:368-73.

25. Andreassen $T T$, Oxlund $H$. Local anabolic effects of growth hormone on intact bone and healing fractures in rats. Calcif Tissue Int. 2003;73:258-64.

26. Laursen M, Hoy K, Hansen ES, Gelineck J, Christensen FB, Bunger CE. Recombinant bone morphogenetic protein-7 as an intracorporal bone growth stimulator in unstable thoracolumbar burst fractures in humans: preliminary results. Eur Spine J. 1999;8:485-90.

27. Kaneko $\mathrm{H}$, Arakawa $\mathrm{T}$, Mano $\mathrm{H}$, Kaneda $\mathrm{T}$, Ogasawara A, Nakagawa $\mathrm{M}$, Toyama $\mathrm{Y}$, Yabe Y, Kumegawa M, Hakeda Y. Direct stimulation of osteoclastic bone resorption by bone morphogenetic protein (BMP)-2 and expression of BMP receptors in mature osteoclasts. Bone. 2000;27:479-86.

28. Jeppsson C, Astrand J, Tagil M, Aspenberg P. A combination of bisphosphonate and BMP additives in impacted bone allografts. Acta Orthop Scand. 2003;74:483-9.

29. Aspenberg P, Basic N, Tägil M, Vukicevic S. Reduced expression of BMP-3 due to mechanical loading: a link between mechanical stimuli and tissue differentiation. Acta Orthop Scand. 2000;71:558-62. 
The Journal of Bone \& JoINT SURgery $\cdot$ JBJS. Org Volume $90-\mathrm{A} \cdot$ SUPPLEMENT $1 \cdot 2008$
Critical Issues in Translational and Clinical Research for the Study of New Technologies to Enhance Bone Repair
30. Bostrom MP, Aspenberg P, Jeppsson C, Salvati EA. Enhancement of bone formation in the setting of repeated tissue deformation. Clin Orthop Relat Res. 1998;350:221-8.

31. Andreassen TT, Ejersted $\mathrm{C}$, Oxlund $\mathrm{H}$. Intermittent parathyroid hormone (1-34) treatment increases callus formation and mechanical strength of healing rat fractures. J Bone Miner Res. 1999;14:960-8.

32. Andreassen $T T$, Fledelius $\mathrm{C}$, Ejersted $\mathrm{C}$, Oxlund $\mathrm{H}$. Increases in callus formation and mechanical strength of healing fractures in old rats treated with parathyroid hormone. Acta Orthop Scand. 2001;72:304-7.

33. Seebach $C$, Skripitz R, Andreassen $T T$, Aspenberg $P$. Intermittent parathyroid hormone (1-34) enhances mechanical strength and density of new bone after distraction osteogenesis in rats. J Orthop Res. 2004;22:472-8.

34. Tanaka M, Sakai A, Uchida S, Tanaka S, Nagashima M, Katayama T, Yamaguchi K, Nakamura T. Prostaglandin E2 receptor (EP4) selective agonist (ONO-4819.CD) accelerates bone repair of femoral cortex after drill-hole injury associated with local upregulation of bone turnover in mature rats. Bone. 2004;34:940-8.

35. Paralkar VM, Borovecki F, Ke HZ, Cameron KO, Lefker B, Grasser WA, Owen TA, Li M, DaSilva-Jardine P, Zhou M, Dunn RL, Dumont F, Korsmeyer R, Krasney P, Brown TA, Plowchalk D, Vukicevic S, Thompson DD. An EP2 receptor-selective prostaglandin E2 agonist induces bone healing. Proc Natl Acad Sci U S A. 2003;100:6736-40.

36. Mundy G, Garrett R, Harris S, Chan J, Chen D, Rossini G, Boyce B, Zhao M, Gutierrez G. Stimulation of bone formation in vitro and in rodents by statins. Science. 1999;286:1946-9.

37. Skoglund $B$, Forslund $C$, Aspenberg $P$. Simvastatin improves fracture healing in mice. J Bone Miner Res. 2002;17:2004-8.

38. Takeda S, Elefteriou F, Levasseur R, Liu X, Zhao L, Parker KL, Armstrong D, Ducy $P$, Karsenty $G$. Leptin regulates bone formation via the sympathetic nervous system. Cell. 2002;111:305-17.

39. Minkowitz B, Boskey AL, Lane JM, Pearlman HS, Vigorita VJ. Effects of propranolol on bone metabolism in the rat. J Orthop Res. 1991;9:869-75.

40. Amanat N, McDonald M, Godfrey C, Bilston L, Little D. Optimal timing of a single dose of zoledronic acid to increase strength in rat fracture repair. J Bone Miner Res. 2007;22:867-76.

41. Seebeck J, Goldhahn J, Städele H, Messmer P, Morlock MM, Schneider E. Effect of cortical thickness and cancellous bone density on the holding strength of internal fixator screws. J Orthop Res. 2004;22:1237-42.

42. Goldhahn J, Reinhold M, Stauber M, Knop C, Frei R, Schneider E, Linke B. Improved anchorage in osteoporotic vertebrae with new implant designs. J Orthop Res. 2006;24:917-25.

43. Dayer R, Rizzoli R, Kaelin A, Ammann P. Low protein intake is associated with impaired titanium implant osseointegration. J Bone Miner Res. 2006;21:258-64.

44. Skripitz R, Aspenberg $P$. Attachment of PMMA cement to bone: force measurements in rats. Biomaterials. 1999;20:351-6.

45. Skripitz R, Aspenberg $P$. Early effect of parathyroid hormone (1-34) on implant fixation. Clin Orthop Relat Res. 2001;392:427-32.

46. Skripitz R, Bohling $S$, Rüther $W$, Aspenberg $P$. Stimulation of implant fixation by parathyroid hormone (1-34). A histomorphometric comparison of PMMA cement and stainless steel. J Orthop Res. 2005;23:1266-70.

47. Moroni A, Faldini C, Hoang-Kim A, Pegreffi F, Giannini S. Alendronate improves screw fixation in osteoporotic bone. J Bone Joint Surg Am. 2007;89:96-101.

48. Hilding M, Ryd L, Toksvig-Larsen S, Aspenberg P. Clodronate prevents prosthetic migration: a randomized radiostereometric study of 50 total knee patients Acta Orthop Scand. 2000;71:553-7.

49. Hilding $M$, Aspenberg $P$. Postoperative clodronate decreases prosthetic migration: 4-year follow-up of a randomized radiostereometric study of 50 total knee patients. Acta Orthop. 2006;77:912-6.

50. Sumner DR, Turner TM, Purchio AF, Gombotz WR, Urban RM, Galante JO. Enhancement of bone ingrowth by transforming growth factor-beta. J Bone Joint Surg Am. 1995;77:1135-47.

51. Sumner DR, Turner TM, Urban RM, Virdi AS, Inoue N. Additive enhancement of implant fixation following combined treatment with rhTGF-beta2 and rhBMP-2 in a canine model. J Bone Joint Surg Am. 2006;88:806-17.
52. Skoglund B, Holmertz J, Aspenberg $P$. Systemic and local ibandronate enhance screw fixation. J Orthop Res. 2004;22:1108-13.

53. Tanzer M, Karabasz D, Krygier JJ, Cohen R, Bobyn JD. Bone augmentation around and within porous implants by local bisphosphonate elution. Clin Orthop Relat Res. 2005;441:30-9.

54. Tengvall $P$, Skoglund $B$, Askendal $A$, Aspenberg $P$. Surface immobilized bisphosphonate improves stainless-steel screw fixation in rats. Biomaterials. 2004;25:2133-8.

55. European Medicines Agency, Committee for Medicinal Products for Human Use. Post-authorisation summary of opinion for Inductos. 2005 Feb 17. EMEA/ 57906/2005. http://www.emea.europa.eu/pdfs/human/opinion/ 5790605en.pdf. Accessed 2007 Nov 1.

56. Fairbank JC, Pynsent PB. The Oswestry Disability Index. Spine. 2000;25: 2940-52.

57. Boden SD, Zdeblick TA, Sandhu HS, Heim SE. The use of rhBMP-2 in interbody fusion cages. Definitive evidence of osteoinduction in humans: a preliminary report. Spine. 2000;25:376-81.

58. Gustilo RB, Anderson JT. Prevention of infection in the treatment of one thousand and twenty-five open fractures of long bones. Retrospective and prospective analyses. J Bone Joint Surg. 1976;58:453-8.

59. Gustilo RB, Mendoza RM, Williams DN. Problems in the management of type III (severe) open fractures. A new classification of type III open fractures. J Trauma. 1984;24:742-6.

60. Govender S, Csimma C, Genant HK, Valentin-Opran A, Amit Y, Arbel R, Aro H, Atar D, Bishay M, Börner MG, Chiron P, Choong P, Cinats J, Courtenay B, Feibel R, Geulette B, Gravel C, Haas N, Raschke M, Hammacher E, van der Velde D, Hardy P, Holt M, Josten C, Ketterl RL, Lindeque B, Lob G, Mathevon H, McCoy G, Marsh D, Miller R, Munting E, Oevre S, Nordsletten L, Patel A, Pohl A, Rennie W, Reynders P, Rommens PM, Rondia J, Rossouw WC, Daneel PJ, Ruff S, Ruter A, Santavirta S, Schildhauer TA, Gekle C, Schnettler R, Segal D, Seiler H, Snowdowne RB, Stapert J, Taglang G, Verdonk R, Vogels L, Weckbach A, Wentzensen A, Wisniewski T; BMP-2 Evaluation in Surgery for Tibial Trauma (BESTT) Study Group. Recombinant human bone morphogenetic protein-2 for treatment of open tibial fractures: a prospective, controlled, randomized study of four hundred and fifty patients. J Bone Joint Surg Am. 2002;84:2123-34.

61. European Medicines Agency, Committee for Medicinal Products for Human Use. European Public Assessment Report (EPAR): Osigraft. EMEA/H/C/393. http://www.emea.europa.eu/humandocs/PDFs/EPAR/osigraft/039301en1.pdf. Accessed 2007 Nov 1.

62. Friedlaender GE, Perry CR, Cole JD, Cook SD, Cierny G, Muschler GF, Zych GA, Calhoun JH, LaForte AJ, Yin S. Osteogenic protein-1 (bone morphogenetic protein-7) in the treatment of tibial nonunions. J Bone Joint Surg Am. 2001;83 Suppl 1(Pt 2): S151-8.

63. Council Directive 93/42/EEC of 14 June 1993 concerning medical devices. Official J European Commun. L 169, 12.7.93, 1993.

64. Grainger AJ, Duryea J, Elliott JM, Genant HK. The evaluation of a new digital semi-automated system for the radiological assessment of distal radial fractures. Skeletal Radiol. 2002;31:457-63.

65. Lynch JA, Grigoryan M, Fierlinger A, Guermazi A, Zaim S, MacLean DB, Genant HK. Measurement of changes in trabecular bone at fracture sites using X-ray CT and automated image registration and processing. J Orthop Res. 2004;22:362-7.

66. Madanat R, Moritz N, Larsson S, Aro HT. RSA applications in monitoring of fracture healing in clinical trials. Scand J Surg. 2006;95:119-27.

67. Fitzpatrick R, Davey C, Buxton MJ, Jones DR. Evaluating patient-based outcome measures for use in clinical trials. Health Technol Assess. 1998;2:i-iv, 1-74.

68. Harris JE, MacDermid JC, Roth J. The International Classification of Functioning as an explanatory model of health after distal radius fracture: a cohort study. Health Qual Life Outcomes. 2005;3:73.

69. Committee for Medicinal Products for Human Use (CHMP). Reflection paper on the regulatory guidance for the use of health-related quality of life (HRQL) measures in the evaluation of medicinal products. London: European Medicines Agency (EMEA); 2005. http://www.emea.europa.eu/pdfs/human/ewp/13939104en.pdf. Accessed 2007 Aug 31. 